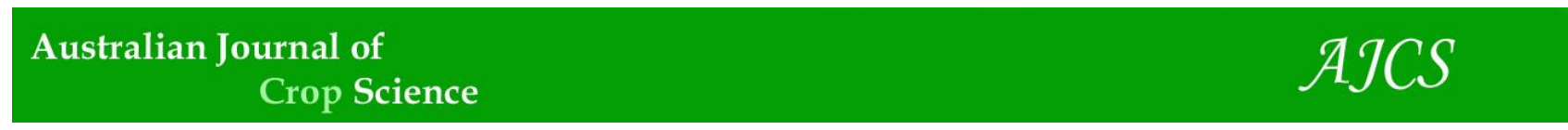

AJCS 11(12):1651-1656 (2017)

ISSN:1835-2707

doi: 10.21475/ajcs.17.11.12.pne895

\title{
Productive viability of sweet pepper (Capsicum chinense [J.] cv. Lupita) using water management with different soil water tensions
}

\author{
Rafaela da Silva Guerino ${ }^{1}$, Joaquim Alves de Lima Junior ${ }^{1}$, André Luiz Pereira da Silva ${ }^{2 *}$, Pedro \\ Daniel de Oliveira ${ }^{1}$, Ivan Carlos Fernandes Martins, ${ }^{1}$, José Félix de Brito Neto ${ }^{3}$, William Lee Carrera \\ de Aviz ${ }^{1}$
}

1'Department of Plant Production, Universidade Federal Rural da Amazônia - UFRA, Capanema, Pará, Brazil
${ }^{2}$ Department of Plant Production, Universidade Estadual Paulista - UNESP, Jaboticabal, São Paulo, Brazil
${ }^{3}$ Department of Soil Fertility, Universidade Estadual da Paraíba - UEPB, Lagoa Seca, Paraíba, Brazil

*Corresponding author: andreengagronomo@gmail.com

\begin{abstract}
Green pepper has a great prominence in the cuisine of Pará. This plant is cultivated using a low technological level along its production chain. However, in the last few years, there has been an increase in planted area due to a national and international recognition of this vegetable, because it is a substitute for bell pepper. This study aims to evaluate the effects of different soil water tension on the productivity of green pepper cv. Lupita. The experiment design was randomized blocks with four replications. The treatments consisted of five soil water tensions: 15, 25, 35, 45 and $55 \mathrm{kPa}$ as indicative for the moment of irrigation. It is concluded that, to obtain high yield and large fruit sizes (longitudinal and transversal diameter), irrigation should be carried out at the moment when soil water tension is close to $33 \mathrm{kPa}$ at a depth of $0.20 \mathrm{~m}$. To obtain a better efficiency in water use, the irrigation should be performed at a tension close to $30 \mathrm{kPa}$.
\end{abstract}

Keywords: nitrogen; Irrigation management; Soil.

Abbreviations: N_nitrogen; PHe_plant height; CD_canopy diameter; FD_fruit diameter; FL_fruit length;PROD_productivity.

\section{Introduction}

Pepper (Capsicum chinense J.), cultivar Lupita, also known as green pepper, is part of the group of sweet peppers. The fruits of this species have an annular constriction, allowing an easy differentiation from other species with a high degree of genetic similarity. The greatest diversity of this species occurs in the Amazon River Basin, and the first cultivations of this species were performed by local natives. Currently, this crop is grown mostly in small areas by family farmers (Reifschneider and Ribeiro 2008).

The area planted with peppers in Brazil is estimated at 5,000 hectares annually, resulting in a production of 75 tons. The growing demand by consumer markets (internal and external) has provided an expressive increase in the area cultivated with peppers (sweet and spicy). The establishment of agroindustries in several Brazilian regions also fostered such increase in area (Moura et al., 2013).

Pepper is a vegetable sensitive to water deficit. This sensitivity is most clearly evidenced during the flowering and the fruiting phase. Both quantity and quality of fruits are adversely affected by it (Doorembos and Kassam 2000). The effects of water deficit on production have been studied by several authors in greenhouses and in field conditions (Biblico et al., 2010; Oliveira et al., 2011).

In order to ensure the most adequate water use, it is necessary to discuss technical criteria already established, such as choice of irrigation system, water blades and timing of application, which will provide a greater productivity and, consequently, a better economic return. Drip irrigation is the most recommended for the cultivation of pepper plants since it tends to provide water application with a greater uniformity, fertigation efficiency, phytosanitary control, less labor and production of fruits with a better quality (Ribeiro et al., 2010; Oliveira et al., 2011).

The Brazilian North Region has high rainfall volumes, but rainfalls are not evenly distributed throughout the year. About $80 \%$ of rainfalls are concentrated between January and July. The months of August and September are favorable to irrigation. The state of Pará presents such characteristics. Among the existing irrigation methods, Sousa et al. (2012) points out that $40.7 \%$ are classified as other methods and/or wetting, which reinforces the importance of an irrigation system using a level of technology and management that meets water needs and ensures a satisfactory crop yield. For Esteves et al. (2010), irrigation requires a high volume of water, requiring a rational use of such technique.

Given the potential of crop expansion and the search for technical information on the productive system for the cultivation of pepper using irrigation, this study aims to evaluate the effects of different soil water tension on the vegetative development and the yield of green pepper cv. Lupita under the conditions of Eastern Amazon.

\section{Results and Discussion}

The water blades applied before (Bef) and after the differentiation of the treatments (Irrig), as well as rainfalls (Rainf) during the experiment, total water provided for the 
crop until harvest (Tot), number of irrigations (NI) and irrigation rounds are presented in Table 1.

It was observed that the total blades applied were higher in the treatments with intermediate tensions levels (T25 and T45) probably because, at those tensions, there was a greater demand for water by pepper to supply its water needs due to a greater growth. This made the tensions reach pre-set values faster. Total water blades applied were lower in extreme treatments (T15 and T55) probably due to a lower water requirement by plants in the treatment $\mathrm{T} 15$, resulting from a higher number of irrigations, and to the lower number of irrigations in the treatment $\mathrm{T} 55$, which had more frequent irrigation rounds.

According to the evaluation of the irrigation system, a Uniform Coefficient of Distribution of Water (UCD) of 95\% was obtained, which favors a greater efficiency in the application of water by drips. The volume of total water supplied throughout the pepper cycle in all treatments was less than the amount of water required for the development of the crop as reported by Lima (2015): 645-800 $\mathrm{mm}$ for long cycle cultivars. Doorenbos and Kassam (1994) reported that, depending on local climatic conditions, crops of the genus Capsicum need a total irrigation blade that may vary from 600 to $1,250 \mathrm{~mm}$. By comparing the results obtained in this study, we verify possible savings of water and energy, directly reflecting in the costs of crop production.

For Azevedo et al. (2005), under the climatic conditions of the city of Pentencoste, Ceará state (CE), the Tabasco pepper showed a good performance with a blade of $1,083 \mathrm{~mm}$ during a cycle of 135 days. The lower water blade applied to the treatments in relation to the volume of water required as reported by other authors may mean a reduction in the water consumption of this crop in that region. Different types of soil and climate must be taken into account and are essential factors to determine the proper water blade for the best development of the crop.

\section{Harvest, productivity and diameter}

The harvesting of pepper began 80 days after transplanting (DAT). The ideal harvest moment was determined visually when fruits reached the maximum growth size, the typical shape of each species and the specific color demanded by the market, according to recommendations (Henz and Moretti 2008).

The results obtained by using different tensions in pepper crops can be seen in Figures 1 and 2. Based on data obtained in this study, it was observed that soil water tension levels affected significantly, at $1 \%$ and $5 \%$ of probability according to F-test, the variables total productivity (TP) $(\mathrm{p} \leq 0.05)$, canopy diameter $(C D)(p \leq 0.01)$, plant height $(p \leq 0.01)$, transverse fruit diameter (TFD) $(\mathrm{p} \leq 0.01)$, longitudinal fruit diameter (LFD) $(p \leq 0.01)$ and water use efficiency (WUE) ( $p$ $\leq 0.05)$.

According to regression analysis of tension factors, a quadratic behavior was verified for all variables, that is, there was an increase in tension from 29 to $33 \mathrm{kPa}$ (Fig 1A, 1B, 1C and 1D), from which the values decreased. It was noted that tensions lower and higher than this range negatively affected the analyzed variables. A quadratic behavior was observed by Bilibio et al. (2010) for eggplant crops, and by Pereira et al. (2016) for cauliflower crops with a productive peak and a consequent productive decrease from that point.

The maximum values estimated based on fit equations were $13.90 \mathrm{t} \mathrm{ha}^{-1}(33 \mathrm{kPa})$ for productivity, and $19 \mathrm{~mm}(32 \mathrm{kPa})$ and $49.7 \mathrm{~mm}(29 \mathrm{kPa})$ for transverse and longitudinal fruit diameter, respectively. The maximum value for productivity found in this study is in line with that obtained by Lima (2015) for sweet pepper crops under the same climatic conditions of this study: maximum productivity of $14 \mathrm{t} \mathrm{ha}^{-1}$ obtained by evaluating different factors of soil water replenishment by class A tanks. In the same line of research of this work and testing different soil water tensions in yellow pepper crops, Frizzone et al. (2001) and Bilibio et al. (2010) obtained a maximum productivity using a tension of $15 \mathrm{kPa}$ for eggplant crops, both in a protected environment. These results confirm that in loco research should be performed, since spatial and temporal variability differ depending on edaphoclimatic conditions, among others.

The longitudinal diameter of the pepper cv. Lupita was higher to that indicated by the seed supplier $(35 \mathrm{~mm})$ and similar, in value, to the transversal fruit diameter. Borroca et al. (2014) reported that the best responses for length and diameter of chili pepper fruits were obtained using a $120 \%$ ETo blade $(624.96 \mathrm{~mm})$

Regarding water use efficiency, the variations can be explained by quadratic regression. It can be seen in Figure 2B that the lowest efficiency in water consumption was verified for extreme treatments, i.e., tensions of 15 and $55 \mathrm{kPa}$, reaching minimum values of 16.62 and $8.8 \mathrm{~kg} \mathrm{ha}^{-1} \mathrm{~mm}^{-1}$, respectively. The highest efficiency response for this variable occurred at a tension of $30 \mathrm{kPa}$, which corresponds to the value of $22 \mathrm{~kg} \mathrm{ha}^{-1} \mathrm{~mm}^{-1}$. Some studies in the literature, conducted using other vegetables, showed that, with an increasing water tension and/or a decreasing water blade applied, the efficiency tends to increase progressively (Lima Júnior et al., 2011a, Vilas Boas et al., 2011a). However, in this study, this behavior was observed from the tension of 30 $\mathrm{kPa}$, as shown in Figure 2B.

The decrease in the absolute values of the variables studied, from the point of tension control of each variable analyzed, is related to tension values close to field capacity. It is possibly due to a characteristic of the pepper itself in responding negatively to a prolonged exposure to a low soil aeration porosity under such conditions. Low aeration porosity may have implied a decrease in the rate of oxygen absorbed by the roots of plants, limiting root respiration and causing crop yields to decrease (Pereira et al. 2016). It is worth noting that irrigations did not exceed field capacity as no water percolation was observed in the soil by the tensiometers installed at a $40 \mathrm{~cm}$ depth. The decrease in such values from critical levels was probably because water begins to be more strongly retained in the soil, and this reduces the availability of water to plants, which require a greater amount of energy to absorb the volume of water required to meet their metabolic needs (Lima Junior et al., 2012b, Vilas Boas et al., 2012b).

As soil tension increases, there is also an increase in water deficit. The upper layers of the soil are the first to dry, causing a loss of superficial roots and deep root proliferation, which can be considered a defense strategy of the plant against drought (Ramos Junior et al., 2013). However, such a strategy requires the assimilation by photosynthesis, which is also limited by water deficit due to the decrease in the supply of $\mathrm{CO}_{2}$ caused by stomatal closure (Albuquerque et al., 2013) at the tips of growing roots. This probably resulted, in this study, in a competition for assimilates between roots and shoots (vegetative phase) and between roots and inflorences (reproductive phase), making both productivity and the other variables mentioned decrease in function of the increasing water tension. 
Table 1. Soil water tensions at $0.20 \mathrm{~m}$. Blades applied before differentiation of treatments (Bef), blades applied after treatment differentiation (Irrig), rainfalls (Rainf), total water blades (Tot), mean blade (meanB), number of irrigations (NI) and irrigation rounds (IR), Igarapé-Açu, PA, 2015.

\begin{tabular}{|c|c|c|c|c|c|c|c|c|}
\hline \multirow[b]{2}{*}{ Treatments } & \multirow{2}{*}{$\begin{array}{c}\text { Tension } \\
(\mathrm{KPa})\end{array}$} & \multicolumn{5}{|c|}{ Blade (mm) } & \multirow{2}{*}{$\begin{array}{c}\text { NI } \\
\text { (un) }\end{array}$} & \multirow{2}{*}{$\begin{array}{c}\mathrm{IR} \\
\text { (days) }\end{array}$} \\
\hline & & Bef & Irrig & Rainf & Tot & meanB & & \\
\hline T15 & 15 & 52.59 & 69.62 & 191.8 & 314.01 & 6.97 & 45 & 1.4 \\
\hline $\mathrm{T} 25$ & 25 & 52.59 & 148.67 & 191.8 & 393.06 & 10.34 & 38 & 2.3 \\
\hline T35 & 35 & 52.59 & 191.76 & 191.8 & 436.15 & 12.82 & 34 & 3.9 \\
\hline T45 & 45 & 52.59 & 125.26 & 191.8 & 369.65 & 20.53 & 18 & 4.7 \\
\hline T55 & 55 & 52.59 & 84.49 & 191.8 & 328.88 & 21.92 & 15 & 5.9 \\
\hline
\end{tabular}

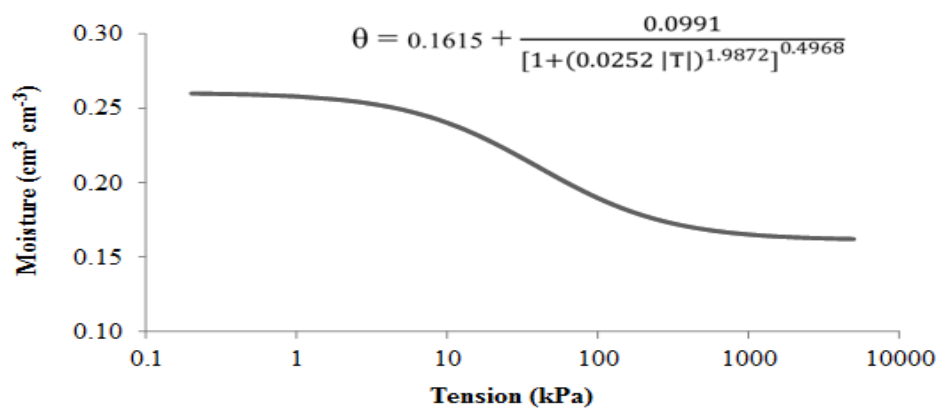

Fig 1. Soil water retention curve. In the equation, the symbols $\theta$ and $\psi$ represent moisture and tension, respectively, Igarapé-Açu-PA, 2015.

A
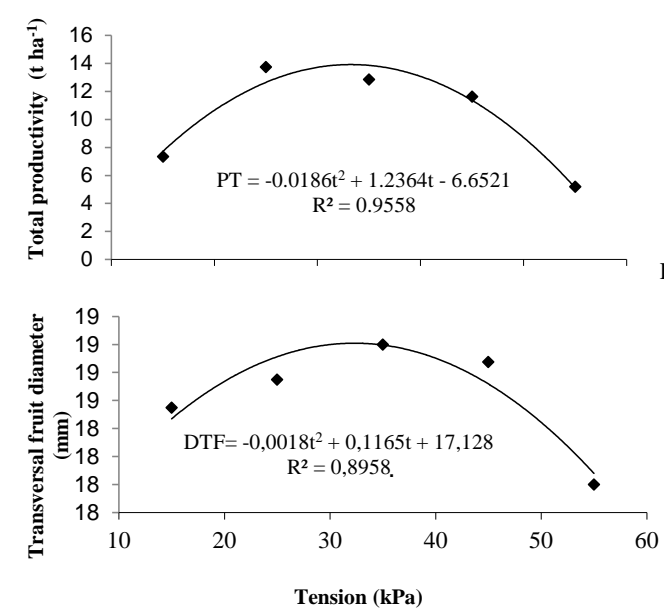

B.
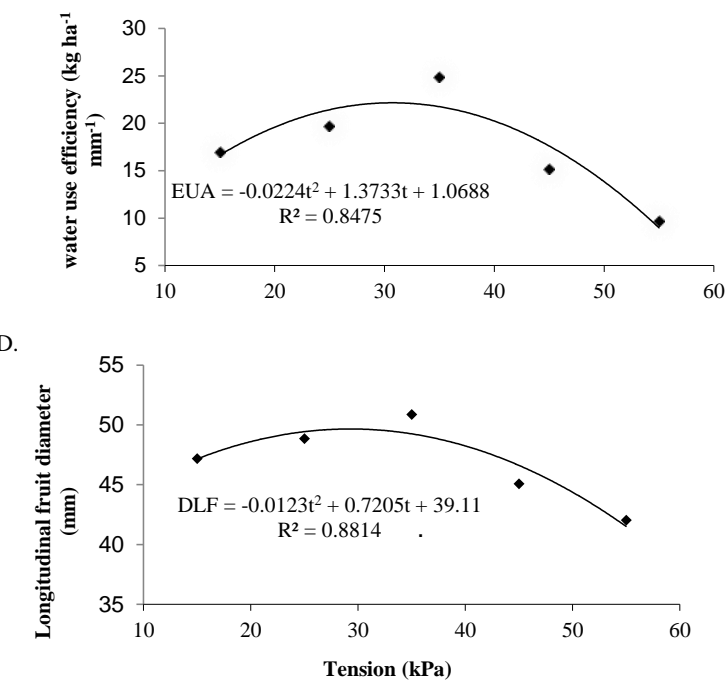

Fig 2. Effects of different values of soil water tension on total productivity (TP), water use efficiency (WUE), transversal (TFD) and longitudinal fruit diameter (LFD), Igarapé-Açu, PA, UFRA, 2015.

A.

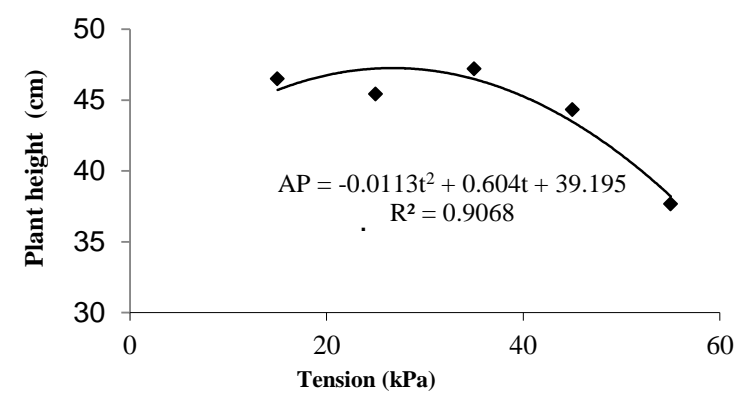

B

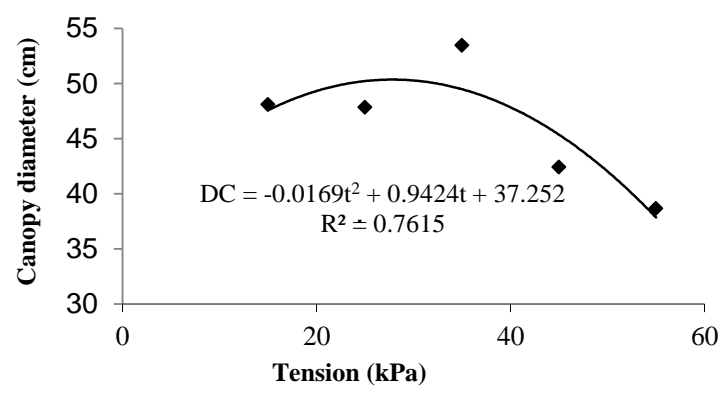

Fig 3. Effects of different values of soil water tension on plant height (PHe) and canopy diameter (CD) of plants, Igarapé-Açu, PA, UFRA, 2015. 


\section{Plant height}

Figure $3 \mathrm{~A}$ and $3 \mathrm{~B}$ show a quadratic behavior in relation to soil water tension, reaching a maximum height of $47 \mathrm{~cm}(27$ $\mathrm{kPa})$ and a maximum canopy of $50 \mathrm{~cm}(29 \mathrm{kPa})$, respectively. This behavior is similar to that identified in this study, and plant height data are within the range determined by Smith \& Heiser (1957): $45-76 \mathrm{~cm}$ for the cultivar Capsicum chinense. Such variation may be related to different irrigation blades. Marinho (2011) observed that the growth in height of the cv. Tabasco presented a $14 \%$ difference between the lowest and the highest irrigation blade imposed at 116 DAT. Rezende et al. (2002) also evidenced that plant height is influenced by the volume of water applied.

Ati et al. (2012) stated that water is one of the most important compounds in an active plant, constituting more than $80 \%$ of the growing tissue. Based on data of response to the treatments applied, when the availability of water in the root environment was restricted from the tension of $28 \mathrm{kPa}$, there was a decrease in both height and canopy of plants. Possibly because of such tension, there was an activation of the plant's defense mechanism, causing a decrease in stomatal opening and, consequently, a decrease in cellular turgescence (Guimarães et al. 2011), affecting the vegetative development of plants.

\section{Materials and Methods}

\section{Plant materials}

The cultivar Lupita used in this study has a cycle of 120 days. The cultivar is characterized by vigorous plants with a light green foliage and sweet and aromatic fruits. The seedlings were obtained by sowing in expanded polystyrene trays containing 200 cells on July $1^{\text {st }}, 2015$. To fill the cells of the trays, the commercial substrate Plantmax ${ }^{\circledR}$ HT was used. After sowing, the trays were taken inside a greenhouse with shading and irrigation, which was performed twice a day (one in the early morning and one in the late afternoon). The greenhouse was located in the Olive Growing Sector of the Experimental Farm of Igarapé-açu. The trays remained in the greenhouse until the opportune moment to be transplanted to the soil.

\section{Climatic aspects}

During the conduction of the experiment, the average daily air temperature was $27^{\circ} \mathrm{C}$. These values corroborate with those identified by Pinto et al. (2006), who indicated a range of $21-35^{\circ} \mathrm{C}$ as satisfactory for the development of pepper. Very high temperatures cause a decrease in crop growth and yield mainly due to a shortening of its development cycle and an increased respiration of the plant tissue (photorespiration and dark phase of respiration) (Streck and Alberto 2006). The relative humidity during the experiment was $88 \%$, within the range recommended by Filgueira (2008), who stated that $80 \%$ is the average relative humidity that provides the best performance for pepper production. Therefore, high temperatures together with low humidity not only are harmful to the development of sweet peppers, but also cause a decrease in fruit productivity and quality.

\section{Experimental site}

The experiment was conducted in field from June to December 2015 at the Experimental Farm of the Federal Rural University of Amazônia (UFRA). The geographic coordinates are $1^{\circ} 07^{\prime} 48.47^{\prime \prime} \mathrm{S}$ and $47^{\circ} 36^{\prime} 45.31^{\prime \prime} \mathrm{W}$. The altitude is $54 \mathrm{~m}$ at the municipality of Igarapé-Açu, Pará state (PA), located in Northeast Pará.

\section{Type and characteristics of the soil}

The soil of the region was classified as a dystrophic Yellow Argisol with a sandy texture. The mean soil density is $1.60 \mathrm{~g}$ $\mathrm{cm}^{-3}$. The results of fertility and granulometry analyses of the experimental area, obtained from a soil sample collected at the depth $0-0.20 \mathrm{~m}$, are $\mathrm{pH}_{\mathrm{H} 20}=5.2, \mathrm{~N}=0.06 \%$, organic matter $=13.76 \mathrm{~g} \mathrm{~kg}^{-1}, \mathrm{P}=21 \mathrm{mg} \mathrm{dm}{ }^{-3}, \mathrm{Ca}=1.8 \mathrm{cmol}_{\mathrm{c}} \mathrm{dm}^{-3}$, $\mathrm{Mg}=0.5 \mathrm{cmol}_{\mathrm{c}} \mathrm{dm}^{-3}, \mathrm{~K}=0.013 \mathrm{cmol}_{\mathrm{c}} \mathrm{dm}^{-3}, \mathrm{Na}=0.013 \mathrm{cmol}_{\mathrm{c}}$ $\mathrm{dm}^{-3}, \mathrm{BS}=2.33 \mathrm{cmol}_{\mathrm{c}} \mathrm{dm}^{-3}, \mathrm{H}+\mathrm{Al}=2.48 \mathrm{cmol}_{\mathrm{c}} \mathrm{dm}^{-3}, \mathrm{CEC}=$ 4.81; V: $48 \%, \mathrm{~B}=0.52 \mathrm{mg} \mathrm{dm}^{-3}, \mathrm{Cu}=2 \mathrm{mg} \mathrm{dm}^{-3}, \mathrm{Fe}=168$ $\mathrm{mg}^{-3}, \mathrm{Mn}: 1.9 \mathrm{mg} \mathrm{dm}^{-3}$, Zn: $2.9 \mathrm{mg} \mathrm{dm}^{-3}$, and 801,19 and 180 $\mathrm{g} \mathrm{kg}^{-1}$ of sand, silt and clay, respectively.

The soil of the experimental area was prepared using plowing and harrowing after liming, performed 90 days before the transplanting of seedlings. During plowing, $1.5 \mathrm{t}$ $\mathrm{ha}^{-1}$ of limestone was applied, which follows an analysisbased recommendation for soil acidity correction seeking to increase base saturation (V) to $80 \%$. Liming and planting fertilization were performed manually and the cover fertilization was performed by fertigation based on soil chemical analysis, following the formulation used by Zanuzo et al. (2013). The quantities of fertilizers applied were based on recommendations per hectare: $170 \mathrm{~kg}$ of $\mathrm{N}, 250 \mathrm{~kg}$ of $\mathrm{P}_{2} \mathrm{O}_{5}$ and $250 \mathrm{~kg}$ of $\mathrm{K}_{2} \mathrm{O}$. All the phosphorus was applied in holes as single superphosphate and goat manure containing organic matter (at $20 \mathrm{~cm}$ depth). The potassium fertilization $\left(250 \mathrm{~kg} \mathrm{ha}^{-1}\right.$ of $\left.\mathrm{K}_{2} \mathrm{O}\right)$, containing potassium chloride, and nitrogen fertilization (170 kg ha ${ }^{-1}$ of $\mathrm{N}$ ) containing urea were supplied in installments every 15 days during the crop cycle: one installment at planting and three coverage installments. Manual weeding was performed during the first 60 days after transplanting (DAT).

\section{Treatments and experimental design}

The experimental design was randomized blocks with 5 treatments and 4 replications. The treatments consisted of five soil water tension $(15,25,35,45$ and $55 \mathrm{kPa})$ as indicative of the moment of irrigation (critical tension). Each plot had $4 \mathrm{~m} \mathrm{x}$ $2.40 \mathrm{~m}$. Two plant lines spaced $0.80 \mathrm{~cm}$ apart and $1.20 \mathrm{~m}$ between rows were opened, totaling ten plants per plot. The central plants were considered useful, two were discarded at the beginning and two were discarded at the end of the lines (a useful plot had 6 plants).

The seedlings were transplanted to the area on September 4, 2015. After transplanting, they were irrigated for 30 days prior to the differentiation of treatments. This is necessary for it is the adaptation phase of plants to the area. Throughout the development of the crop, the following procedures were performed: manual weeding to control weeds, application of the insecticide Actara to control aphids, and application of a systemic fungicide to control anthracnose. Both applications were carried out using a manual backpack sprayer.

The plants were irrigated using drip irrigation at a flow rate of $2.0 \mathrm{~L} \mathrm{~h}^{-1}$. The emitters were spaced $20 \mathrm{~cm}$ apart. Irrigation was performed using self-compensating polyethylene drip hoses with a nominal diameter of $16 \mathrm{~mm}$, an operating pressure of 8 m.c.a at the end of the hose, and in-line emitters. The drip hoses were positioned inside the plot on the soil surface, so that each hose containing 20 emitters irrigated one line of plants (total of 40 emitters/plot). The side pipes were connected directly to the main PVC pipes, where 
electric control valves, located at the exit of the control head, were installed at the pipe entry tip. One valve was used for each treatment. The valves were driven by a controller previously programmed at each irrigation to run for the time needed to replenish the irrigation blade. In all irrigations, we sought to raise the moisture level, corresponding to the tension at the moment of irrigation, up to the moisture at field capacity (Cabello 1996).

An irrigation system of 5,000 liters, an electric pump of $1 / 2$ $\mathrm{hp}$, a disk filter and a pressure regulating valve of 10 m.c.a installed at the exit of the main pipe were used for the irrigation system.

After the installation of the irrigation system, hydraulic evaluations were conducted to determine its performance considering the Uniform Distribution Coefficient (UDC). The analysis of uniformity was performed in twelve plots. Three plots of each treatment were related to different tension levels. $50 \mathrm{~mL}$ collection vessels were placed under the six central emitters, collecting water for a period of $2 \mathrm{~min}$. The UDC was calculated by the averages of the blades collected.

A set of five tensiometers per plot (two at the depth $0.20 \mathrm{~m}$ to monitor irrigation and two at the depth $0.40 \mathrm{~m}$ to verify the occurrence of percolation) was installed to monitor the soil water energy status. For each treatment, tensiometer sets were installed in two of the four replicates. The tensiometers were installed in alignment with the crop between two plants, and were $0.20 \mathrm{~m}$ apart from each other in each set. The readings on the tensiometers were performed in the morning, up to 9 a.m., using a digital puncture tensiometer. Irrigation management was based on the characteristic retention curve obtained at the $0-20 \mathrm{~cm}$ soil profile (Fig. 1). The irrigations were carried out when at least one of the tensiometers, or two on average, reached a critical tension, always seeking to raise the soil moisture to its field capacity, which corresponds to a tension of $10 \mathrm{kPa}$.

The soil characteristic water curve was determined by the Soil Physics Laboratory of the Institute of Agricultural Sciences of UFRA. It determined low tension points $(0,2,4$, $6,8$ and $10 \mathrm{kPa})$ and high tension points $(33100,500$ and $1,500 \mathrm{kPa}$ ). Using the software SWRC, the model proposed by Van Genuchten (1980), which describes the behavior of soil moisture in function of voltage (matrix potential), was adjusted. From this equation and the observed values, the soil water retention curve was generated for the layer under analysis.

Soil water tensions, equivalent to moisture at field capacity, was obtained locally using the methodology proposed by Bernardo et al. (2005). After obtaining the tension value and using the equation mentioned above, the moisture content at field capacity, corresponding to the soil layer $0-0.20 \mathrm{~cm}$, was calculated.

The water depths applied to treatment differentiation and irrigation system functioning time were calculated according to Cabello (1996), considering an effective depth of the root system equal to $20 \mathrm{~cm}$ and a water application efficiency of the drip irrigation system equal to $95 \%$.

\section{Characteristics evaluated}

In order to evaluate the effects of irrigation management, the following parameters were analyzed: biometrics (plant height - PHe, canopy diameter - CD), fruit diameter (FD, mm), fruit length (FL, mm) and productivity (PROD). Plant height measurements were performed using a measuring tape in $\mathrm{cm}$. The fruits were measured using a caliper. Biometry was performed at 30 DAT (Days After Transplanting). PHe was determined from the base of the plant, close to the soil, up to the maximum average height of apical leaves. The CD consisted of the average of two perpendicular diameters by measuring the distance between the tips of the plant.

\section{Statistical analysis}

Analyses of variance and polynomial regressions of the data were performed. The equation that presented a significant $F$ and the highest coefficient of determination was chosen.

\section{Conclusion}

In order to obtain a higher yield $\left(13.90 \mathrm{t} \mathrm{ha}^{-1}\right)$ and $(19 \mathrm{~mm}$ longitudinal and $47.9 \mathrm{~mm}$ transverse length), irrigation should be carried out at a time when the soil water tension of around $33 \mathrm{kPa}$ at a depth of $0,20 \mathrm{~m}$. The highest efficiency in water consumption was verified when the irrigation was carried out with the voltage close to $30 \mathrm{kPa}$.

\section{Acknowledgments}

The authors are grateful to $\mathrm{CNPq}$ - National Council for Scientific and Technological Development, for the financial assistance in the accomplishment of this work and the fellowship of Scientific Initiation and the Federal Rural University of Amazonia-UFRA, for the support to the publication.

\section{References}

Albuquerque MPF, Moraes FKC, Santos RIN, Castro GLS, Ramos EMLS, Pinheiro HA (2013). Ecofisiologia de plantas jovens de mogno-africano submetidas a deficit hídrico e reidratação. Pesq Agrop Bras. 48:9-16

Ati AS, Iyada AD, Salah MN (2012) Water use efficiency of potato (Solanum tuberosum L.) under different irrigation methods and potassium fertilizer rates. Annals of Agric Scie. 57:299-103

Azevedo BMD, Chaves WP, Medeiros FdeM, Aquino BF de, Bezerra FML, Viana TVdeA (2005) Rendimento da pimenteira em função de lâminas de irrigação. Ver Ciênc Agron. 36:268-273

Borroca MV, Bonomo R, Souza JM, Fernandes AA (2014) Produção de pimenta "dedo-de-moça" e de "cheiro" em função de lâminas de irrigação no norte capixaba. In: II Inovagri internacional meeting, inovagri. Fortaleza, Ceará

Bernardo S, Soares AA, Mantovani EC (2005) Manejo da irrigação. $7^{\mathrm{a}}$ (eds). UFV, Viçosa, 611.

Bilibio C, Carvalho JA, Martins M, Resende FC, Freistas EA, Gomes LA A (2010) Desenvolvimento vegetativo e produtivo da berinjela submetida a diferentes tensões de água no solo. Rev Bras Eng Agr Ambi. 14:730-735

Cabello FP (1996) Riegos localizados de alta frecuencia (RLAF) goteo, microaspersión, exudasión. $3^{\mathrm{a}}$ (eds). Madrid: Mundi-Prensa, 511

Doorenbos J, Kassan AH (1994) Efeito da água no rendimento das culturas. Campina Grande: UFPB, Campina Grande 360.

Esteves BdosS, Mendonça JC, Sousa EF, Bernardo S (2010) Avaliação do Kt para estimativa da evapotranspiração de referência (ETo) em Campos dos Goytacazes, RJ. Rev. Bras Eng Agríc. Ambie. 14:274-278

Filgueira FA (2008) (ed) Novo manual de olericultura: agrotecnologia moderna na produção e comercialização de hortaliças. 3a Viçosa: UFV, Minas Gerais 242.

Frizzone JA, Gonçalves ACA, Rezende R (2001) Produtividade do pimentão amarelo Capsicum annum L., 
cultivado em ambiente protegido em função do potencial mátrico de agua no solo. Acta Sci. 23:1111-1116

Guimarães CM, Stone LF, Oliveira JP, Rangel PHN, Rodruigues CAP (2011) Sistema radicular do arroz de terras altas sob deficiência hídrica. Pesq Agrop Trop. 41:126-134

Henz GP, Moretti CL (2008) Colheita e pós-colheita. (eds) In: Ribeiro CSDC (ed) Pimentas Capsicum. Embrapa Hortaliças, Brasília. 156.

Lima Junior JA, Pereira GM, Geisenhoff LO, Costa GG, Reis RP, Oliveira LFC (2011a) Avaliação econômica da produção de alface americana em função de lâminas de irrigação. Ciênc e Agrotec. 35:392-398

Lima Júnior JA, Pereira GM, Geisenhoff LO, Silva WG, Vilas Boas RC, Souza RJ (2012b) Desempenho de cultivares de cenoura em função da água no solo. Ver. Bras. Eng Agrí Amb. 16: 514-520

Lima VM (2015) Produção e análise econômica de pimentinha verde (capsicum chinenses j.) submetida a diferentes lâminas de irrigação na região nordeste paraense. (Mestrado em Agronomia) - Universidade Federal Rural da Amazônia, Belém, 44.

Marinho LB (2011) Irrigação plena e com déficit em pimenta cv. Tabasco em ambiente protegido. (Doutorado em Ciências) - Escola Superior de Agricultura "Luiz de Queiroz", Universidade de São Paulo, Piracicaba, 102.

Moura AP, Filho M, Guimarães JA, Amaro GB, Liz RSde (2013) Manejo integrado de pragas de pimentas do gênero Capsicum. Brasília, DF.

Oliveira EC, Carvalho JA, Rezende FC, Freitas WA (2011) Viabilidade técnica e econômica da produção de ervilha (Pisum sativum L.) cultivada sob diferentes lâminas de irrigação. Eng Agrí. 31:324-333

Pereira MEM, Lima Junior JA, Souza RORM, Gusmão SAL, Lima VM (2016) Irrigation management influence and fertilizer doses with boron on productive performance of cauliflower. Eng Agrí. 36:811-821

Pinto CMF, Puiatti M, Caliman FRB, Moreira GR, Mattos RN (2006) Clima, época de semeadura, produção de mudas, plantio e espaçamento da cultura da pimenteira. Informe Agropecuário. Belo Horizonte, Minas Gerais, 49.
Ramos Junior EU, Machado RAF, Olibone D, Castoldi G, Ramos BM (2013) Crescimento de plantas de cobertura sob déficit hídrico. Semina: Ciênc Agrá. 34:47-56

Rezende FC, Frizzone JÁ, Pereira AS, Botrel TA (2002) Plantas cultivadas em ambiente protegido com CO2. II. Produção de matéria seca. Acta Scient. 24:1527-1533

Ribeiro PAA, Coelho RD, Teixeira MB (2010) Entupimento de tubos de gotejadores convencionais com aplicação de Cloreto de Potássio (branco e vermelho) via duas qualidade da água. Eng Agrí. 30:279-287

Reifschneider FJB, Ribeiro CSD (2008) Cultivo. In: Ribeiro CSDC (eds) Pimentas Capsicum. Brasília: Embrapa Hortaliças, 14.

Smith PG, Heiser CB (1957) Taxonomy of Capsicum chinense Jacq. and the geographic distribuition the cultivated Capsicum species. Boletim of the Torrey Botanical Club, 420

Streck NA, Alberto CM (2006) Simulação do impacto da mudança climática sobre a água disponível do solo em agroecossistemas de trigo, soja e milho em Santa Maria, RS. Ciênc Rur. 36: 424-433

Souza RORM, Pantoja AV, Amaral MACM, Pereira Neto JA (2012) Cenário da agricultura irrigada no Estado do Pará Irrig.17:177-188

Van Genuchten MTH (1980) A closed-form equation for predicting the hydraulic conductivity of unsaturated soils. Soil Sci Soc Americ J. 44:892-898

Vilas Boas RC, Pereira GM, Souza RJ, Consoni R (2011a) Desempenho de cultivares de cebola em função do manejo da irrigação por gotejamento. Rev. Bras. Eng Agrí Amb.15:117-124

Vilas Boas RC, Pereira GM, Souza RJ, Geisenhoff LO, Lima Júnior JA (2012b) Desenvolvimento e produção de duas cultivares de cebola irrigadas por gotejamento. Rev Bras Eng Agr Ambi. 16:706-713

Zanuzo MR, Ribeiro LM, Lange A, Machado RAF, Massaroto JA (2013) Desempenho agronômico de genótipos de couve-flor nas condições edafoclimáticas de Sinop. Hort Bras. 31:332-337 